\title{
Determinants of Customer Loyalty: Evidence from Indonesian Retail Market
}

\author{
Suresh Kumar* \\ Business Administration Department, President University, Jawa Barat, Indonesia
}

*Corresponding Author: Suresh Kumar, Business Administration Department, President University, Jawa Barat, Indonesia

\begin{abstract}
Retail industries are one of the largest employed workers in Indonesia accounted for 26 million workers. The fierce competition among modern retailers in Indonesia forces some of the retailers had to close down their business, as the result, it would lead to mass unemployment in Indonesia. The objective of this research is to determine the customer loyalty factors in retail industries in Indonesia as one of the strategies to stay in the competition. Based on the literature review it was found that Brand Image, Satisfaction, and Reputation play a significant role in determining loyalty. Hence, this research is aimed to analyze the relationship among Brand Image, Satisfaction, Reputation and Loyalty. Hero supermarket was chosen as the case looking at the previous prediction it would go defeating its competitors in 2012 whereas in 2015 it had to close down some of its stores and even sold one of its business units. Furthermore, Hero declined to second place based on the Brand Image Award. The relationship among brand image, satisfaction, reputation, and loyalty was analyzed by applying quantitative research approach with 270 respondents with the criteria those who have bought at least once at Hero in the West Jakarta and Structural Equation Modelling was used to test the hypothesis. The results showed that Brand Image influences satisfaction and reputation but not loyalty, whereas reputation does not influence loyalty but satisfaction does.
\end{abstract}

Keywords: Brand Image, Satisfaction, Reputation, Loyalty

\section{INTRODUCTION}

Retail businesses in Indonesia employ 26 million employees up to August 2016 (Pulungan, 2017) with 36,000 stores all over Indonesia compare to 12,000 traditional stores (Simorangkir, 2017). With the massive growth of various retail categories (convenience stores, $46 \%$; supermarkets, 34\%; hypermarkets, 20\%; Indonesia Grocery Retail Market, 2015) make it easier for consumers to choose the retail store they want. Hence, customers desire to switch high within retail stores. For example, Frontier Consulting Group in 2012 conducted a survey at 11 big cities in Indonesia, namely Jakarta, Bandung, Semarang, Surabaya, Medan, Makassar, Pekanbaru, Balikpapan, Denpasar, Palembang and Samarinda to measure consumer-switching behavior, with the attributes such as top of mind, the last use and future desires, for hypermarkets, supermarkets and mini-markets in Indonesia (Apipudin, 2012). The result was Carrefour, Hypermart and Lotte Mart brands were predicted to increase in terms of visitors in the future for the category of hypermarkets. On the other hand, Giant, Superindo, and Brastagi in the same category had negative net switching. But in 2016 Carrefour, Giant and Hypermart received the Top Brand Award. In the supermarket category, Hero was the only brand predicted to have the number of visitors increased in the future compare to Superindo, Griya, and Tiptop which had negative net switching. However, the prediction of Frontier Consulting Group went wrong and Hero closed down their Convenience Store unit, Starmart between 2014-2015 and finally, sold them to PT FajarMitra Indah (Sumartomdjon, 2016). Furthermore, Hero has closed down 22 Guardian stores, 10 other stores consisted of Giant Ekspres, Hero Supermarket, and Giant Ekstra (Pasopati, 2015) due to economic conditions resulting in weak purchasing power of the people. As for Superindo which is in the same supermarket category predicted to be declined by Frontier Consulting Group before has been awarded as the first Top Brand Award 2016; whereas Hero is placed second (Topbrand-award, 2016). As for the mini-mart category, Alfamart, Yomart, and 7-eleven were the brands that the number of visitors in the future predicted increased due to positive net switching, whereas Indomaret and Alfamidi had negative brand switching. Despite this prediction, Indomaret 
and Alfamart received Top Brand Award 2016. Thus, if any of the retail business fails to address the competition they will end up closing down their stores and many will lose their jobs.

Having Top Brand is necessary since it is an aggregation of convictions and perspectives about that specific brand. Furthermore, it has possessed the capacity to make a picture that characterizes trust, expectation, and conviction that resulting in satisfactory by using it (Bhasin, 2016). However, the strong brand image alone does not guarantee repeat customers, but loyalty does (Neupane, 2015). He even concludes that it is vital to represent that if a client is pleasure with the item he/she is intrigued to, indicate the faithful towards the brand; i.e. willing to pay even more, willing to give a positive informal exchange and to show steadfast practices. In addition, Gallarza, Ruiz-Molina, and Gil-Saura (2016) found that satisfaction is another factor influences loyalty that is also supported by Martenson (2007) and Abrudan, Plăiaş, Dabija. (2017). She also added that brand image influences satisfaction and only a few segments of customer loyalty to the brand. On the other hand, Neupane (2015) found that not only Brand Image influences loyalty mediated by satisfaction but also it directly influences loyalty. Reputation is also considered as other factors that influences loyalty (Benoit, 2015) which is also confirmed by Ruiz, Garcia \& Revilla (2016).

However, only a few empirical studies have analyzed what factors triggered customer loyalty in supermarket context and there is no research found linking brand image, reputation, satisfaction, and loyalty so far. Hence, this study contributes to the literature on the subject by adding previous studies in regards to factors determining loyalty in supermarket industries through brand image, reputation, and satisfaction. This research paper is structured as follows: a theoretical background on the constructs of the current study as well as the hypothesis development is provided on section two (literature review), while methods (section three) provide samples used and procedures to get respondents, and construct measurement. Statistical analysis on the respondents' demography is also provided along with the validity and reliability testing and model fit. Results (section four) answer the hypotheses being developed and managerial implications and direction for future research are also given in section five.

\section{LITERATURE REVIEW}

\subsection{Loyalty}

According to Soon-Ho, Min-Seoung and Dong-Hun (2016) loyalty are a long-term key success of any companies because they believe that loyal customers are difficult to be hijacked by other competitors even through lower price strategy. In addition, Gallarza et al (2016) express loyalty as a deep commitment of existing customers to keep on purchasing either products or services to the same company despite the temptation given by other competitors. Loyalty can be reached through customer satisfaction (Gallarza et al, 2016; Soon-Ho, Min-Seoung and Dong-Hun, 2016; Neupane, 2015), brand image (Seric, Gil-Saura and Molla-Descals, 2016; Neupane, 2015; Lahap, Ramli, Said, Radzi and Zain, 2015) and store reputation (Ruiz et al., 2016; Lauritsen and Perks, 2015; Goldring, 2015).

\subsection{Brand Image}

Brand Image is the impression of customers regarding a product or service that gives a benefit (Keller, 2003). In addition, the American Marketing Association (2013) defines Brand Image as a unique feature provided by a company to differentiate itself to the others. According to Fianto, Hadiwidjojo, Aisjah, \&Solimun (2014), Brand Image is additionally alluded to as the client's view of either the reason or discerning premise or through more feelings towards a particular brand. Furthermore, they added, Brand Image is likewise viewed as a portrayal of the offer of the organization that incorporates the typical significance related clients through particular characteristics of the items or administrations.

Based on the research conducted by Neupane (2015) at a Tesco store situated in Woolwich, London, Brand Image influences Satisfaction and Brand Image influences Loyalty. Furthermore, a research conducted in Malaysian Hotel Industry by Lahap et al. (2016) found that Brand Image strongly influences Satisfaction. Manthiou, Kang, and Schrier (2014) further strengthen the relationship between Brand Image and Loyalty based on their research on a community festival called VEISHEA in the state of Iowa. Therefore, brand image is believed to be positively influences satisfaction and loyalty (Figure 1).

H1: Brand Image positively influences Satisfaction

H2: Brand Image positively influences Loyalty 


\subsection{Reputation}

Reputation is not yet used as a proportionate word for terms, such as character, image, prestige, social obligation, affiliation, reference, word of mouth and others (Verčič, Verčič, \& Žnidar, 2016; Benoit, 2015). Furthermore, Verčič et al. (2016) argue that reputation may be an estimate of the best approach associated with experienced both, internally, among representatives, and externally, around different stakeholder groups, in regards to regulate a community. Reputation is a gathering of learning and feeling of a person or other entity that associated with an origination (Aarikka-Stenroos, 2014). In the South-East of UK, Lauritsen \& Perks, (2015) a studied on brand image for customers of household grocery shopping and regularly shop proved that brand image significantly influenced reputation. A different study in a bank industry conducted by Foroudi, Melewar, \& Gupta (2014) in Hongkong also give a positive result that reputation is influenced by brand a image. A study by Cretu \& Broderick (2007) in New Zealand on three manufacturers selling shampoo to a beauty parlor also identified that a brand image correlated positively with reputation. Hence, it is believed that brand image positively influences reputation (Figure 1).

\section{H3 : Brand Image positively influences Reputation}

Joshi \& Singh (2017) study the impact of perceived corporate reputation on customers' loyalty in the telecom industry in India and found that high telecom reputation impacts on customers' loyalty. Furthermore, García de Leaniz \& del Bosque Rodriques (2016) found that reputation is the driver for customer loyalty based on their study of Spanish consumers in a service setting. In addition, Foroudi, Jin, Gupta, Melewar, Foroudi (2016) found that even in retail settings using international retail brands in London, reputation influences customer loyalty. Moreover, in the automotive industries, reputation is found as a better driver on loyalty compares to brand attachment (Loureiro, Sarmento, \& Le Bellago, 2017). Thus, this research stands for reputation is the driver of loyalty (Figure 1).

H4 : Reputation positively influences Loyalty

\subsection{Satisfaction}

Satisfaction is a foundation from claiming shopper self-destructive considerations and conduct and the promoting management expositive expression (Gallarza et al., 2016). Satisfaction may be a disposition of a sort evaluation by customers to a retail store comprehensively dependent upon the correlation between the discerned furthermore required executions of the store (Nesset et al., 2011). Satisfaction is characterized by the blend of both love (feeling) and cognizance approach as "the buyer's satisfaction reaction (Gallarza et al., 2016). Satisfaction is the positive judgment of general administration encounters with a specialist organization and results in a full of feeling state for buyers (Dagger and O'Brien, 2010). Satisfaction is full of feeling reaction taking after a hope disconfirmation encounter that includes a psychological (Gallarza et al., 2016). Satisfaction is a reaction of buyers' reaction after purchase. Soon-Ho, Min-Seong, Dong (2016) conducted a research in a coffee shop industry in South Korea and found out that Satisfaction influences Loyalty. The result strengthens the findings of Ruiz et al. (2016) that satisfaction influences Loyalty in a bank industry in UK and Spain. Therefore, satisfaction is considered the main influencer to loyalty (Figure 1).

H5 : Satisfaction positively influences Loyalty

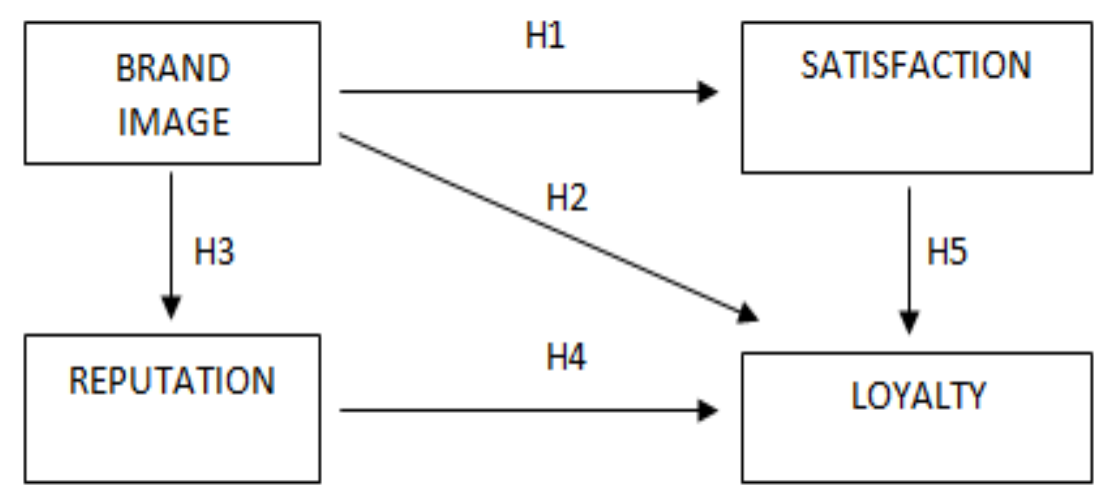

Figure1. Theoritical Framework 


\section{METHODS}

\subsection{Samples and Procedures}

In this research, a quantitative research was applied with a survey method. The questionnaire was compiled from previous researchers and then was discussed with two English lecturers who were native Indonesians and two from retail experts and Academic Professors. Further, a pilot test was performed with 11 customers of Hero Supermarket checking on the wording and their understanding of the questionnaires as suggested by Malhotra (2011). Several questions were then revised based on the feedback given and the final draft of the questionnaire was ready. The copy of questionnaires used both English and Indonesia language since the respondents were Indonesians, hoping to get a better result by using their own mother tongue. The population was Hero's customers who have bought a product at least once at Hero Supermarket within 3 months. The location of distribution was concentrated at Jakarta Barat where Hero Supermarket opens its branch (Puri Indah Mall, Taman Anggrek, and Mall Ciputra) only. There were 400 questionnaires distributed, but only 270 (67.5\%) responded fully and counted in this study. The sampling technique used was random sampling; respondents chosen were every third customer coming out of the store entrance. Purposive sampling was also applied by approaching Hero's customers who came out of the store assuming that they were regular customers and have at least shopped once at Hero Supermarket as the eligible respondents. The research was conducted starting in the middle of January 2017 until the end of April 2017.

\subsection{Measures}

To measure the constructs, multiple items were developed based on previous researches tested items with a seven-point Likert-type scale from "strongly disagree" and "strongly agree" options.For Brand Image, the construct was measured with 6 items from the work of Keller (2003), Sondah, Omar, Ismail, Ishak\&Harun (2007) and Kremer \&Viot (2012). As for Satisfaction, the construct was measured with 4 items from the work of Sondah et al. (2007), Sooh-Ho, Min-Seong\&Lee (2016), and(Gallarza et al., 2016). Reputation construct was measured with 5 items developed from Kim \& Lennon (2013), Kim, Yang \& Kim (2013), and Xie, Bagozzi\&Meland (2015). And lastly for Loyalty construct, it was measured with 5 items from the work of Pleshko\& Heiens (2015) and Dick \&Basu (1994).

\subsection{Statistical Analysis}

From gender based most of the respondents were female (62.6\%) followed by male $(37.4 \%)$. The majority of the respondents were in the range of 21-24years old (54.7\%) followed by 25-30 years old $(41.1 \%)$ and above 35 were $4.2 \%$. While for expenditure level, the majority respondents were from IDR 1,000,000 - 2,500,000 (50\%) followed by IDR 2,500,001 - 4,000,000 got (10\%) and above IDR $4,000,001$ for about $13.3 \%$ (Table 1 ).

Table1. Sample Distribution

\begin{tabular}{|c|c|c|}
\hline & $\mathbf{N}$ & $\%$ \\
\hline \multicolumn{3}{|c|}{ Gender } \\
\hline Male & 101 & 37.4 \\
\hline Female & 169 & 62.6 \\
\hline \multicolumn{3}{|c|}{ Age } \\
\hline$>30$ & 12 & 4.2 \\
\hline $21-24$ & 147 & 54.7 \\
\hline $25-30$ & 111 & 41.1 \\
\hline \multicolumn{3}{|c|}{ Education } \\
\hline Entrepreneur & 11 & 4.1 \\
\hline Manager & 6 & 2.2 \\
\hline Housewife & 8 & 3.0 \\
\hline Employee & 21 & 7.8 \\
\hline Student & 224 & 83.4 \\
\hline \multicolumn{3}{|c|}{ Expenses } \\
\hline$<1,000,000$ & 72 & 26.7 \\
\hline$>7,000,000$ & 13 & 4.8 \\
\hline $1,000,000-2,500,000$ & 135 & 50 \\
\hline $2,500,000-4,000,000$ & 27 & 10 \\
\hline $4,000,000-5,500,000$ & 16 & 5.9 \\
\hline $5,500,000-7,000,000$ & 7 & 2.6 \\
\hline
\end{tabular}


Further, measured items were checked on the construct validity using confirmatory factor analysis (CFA) with the criteria Average Variance Extracted (AVE) greater than 0.5 and reliability using Composite Reliability (CR) greater than 0.7 (Hair et al, 2010). All measured items have factor loading above 0.44 (Malhotra, 2012)which shows the adequacy of the measurement model. The model has also passed the convergence validity and discriminant validity with AVE ranging from 0.665 to 0.749 and reliability with CR ranging from 0.873 to 0.923 . Except for items that loaded poorly (less than 0.44) were dropped to get a better measurement (Table 2). They were My friends would think highly of me if I visit Hero (BI2); Hero increases my frequency of buy (BI7); Hero offers good quality of products (BI8); and Personally, I consider Hero as being well known (R1).

Table2. Factor Loading, Validity and Reliability

\begin{tabular}{|c|c|c|c|}
\hline Constructs and measured items & Factor Loading & AVE & $\mathbf{C R}$ \\
\hline \multicolumn{4}{|l|}{ LOYALTY } \\
\hline I encourage friends and relatives to do business with Hero (L3) & .827 & 0.679 & 0.914 \\
\hline Hero is my first choice $(\mathbf{L 1})$ & .818 & & \\
\hline I make an effort to use Hero for all of my shopping needs (L5) & .702 & & \\
\hline I will continue buying Hero's products in the future(L4) & .687 & & \\
\hline I say positive things about Hero to other people (L2) & .670 & & \\
\hline \multicolumn{4}{|l|}{ BRAND IMAGE } \\
\hline Hero fits my personality (BI1) & .750 & 0.68 & 0.873 \\
\hline Buyingproduct at Hero makes me feel delighted (BI4) & .749 & & \\
\hline The image of Hero is consistent with my own self-image (BI3) & .687 & & \\
\hline Hero can be dependable to use (BI5) & .669 & & \\
\hline Hero fights for the customer interest (BI6) & .589 & & \\
\hline \multicolumn{4}{|l|}{ REPUTATION } \\
\hline Personally, I consider Hero as prestigious $(\mathbf{R 4})$ & .824 & 0.665 & 0.888 \\
\hline Personally, I consider Hero as respected (R3) & .734 & & \\
\hline Hero has good reputation (R5) & .711 & & \\
\hline Personally, I consider Hero as admired (R2) & .708 & & \\
\hline \multicolumn{4}{|l|}{$\begin{array}{ll} & \text { SATISFACTION } \\
\end{array}$} \\
\hline Hero is my idealshop (S2) & 679 & 0.749 & 0.923 \\
\hline I am delighted to buy productsat Hero (S3) & .664 & & \\
\hline I am satisfied buying productsat Hero (S1) & .620 & & \\
\hline Shopping at Hero is pleasant (S4) & .587 & & \\
\hline
\end{tabular}

Before testing the hypothesis, goodness of fit was checked through AMOS 18.0. The Chi-square was significant $(\chi 2=278.269$, d.f. $=121, \mathrm{p}<0.001)$. The overall evaluation of model fit was checked using various indices: $\mathrm{CMin}=2.300 ; \mathrm{GFI}=0.896 ; \mathrm{AGFI}=.852 ; \mathrm{NFI}=0.932 ; \mathrm{IFI}=0.96 ; \mathrm{TLI}=0.949 ; \mathrm{CFI}$ $=0.96 ; \mathrm{RMSEA}=0.07$

\section{RESUlts}

$\mathrm{H} 1$ addressed that Brand Image positively influences Satisfaction. The result shows that Brand Image indeed has a significant positive influence on Satisfaction $(\beta=.938, C R=11.809, p<0.001)$, hence, $\mathrm{H} 1$ is supported. H2 stated that Brand Image positively influences Loyalty; however it is not supported $(\beta=.074, \mathrm{CR}=.353, \mathrm{p}>0.05) . \mathrm{H} 3$ showed that Brand Image positively influences Reputation $(\beta=.966, \mathrm{CR}=11.815, \mathrm{p}<0.001)$, hence $\mathrm{H} 3$ is supported. H4 demonstrated that Reputation positively influences Loyalty; however it is not supported $(\beta=.120, \mathrm{CR}=1.187, \mathrm{p}$ > 0.05). H5 addressed that Satisfaction positively influences Loyalty. Satisfaction has a significance positive influence on Loyalty $(\beta=.893, \mathrm{CRt}=5.561, \mathrm{p}<0.001)$, thus H5 is supported. As for the squared multiple correlations (SMCs) among Satisfaction (0.796), Reputation (0.689) and Loyalty (0.726) are found to be strong predictors. It is estimated that the predictors of Satisfaction explain 79.6 percent of its variance, with the error variance approximately 20.4 percent of the variance of Satisfaction As for Reputation, it explains 68.9 percent of its variance. In other words, the error variance Reputation is approximately 31.1 percent of the variance of Reputation itself. Whereas Loyalty, it explains 72.6 percent of its variance, with error variance approximately 27.4 percent of the variance of Loyalty itself. 


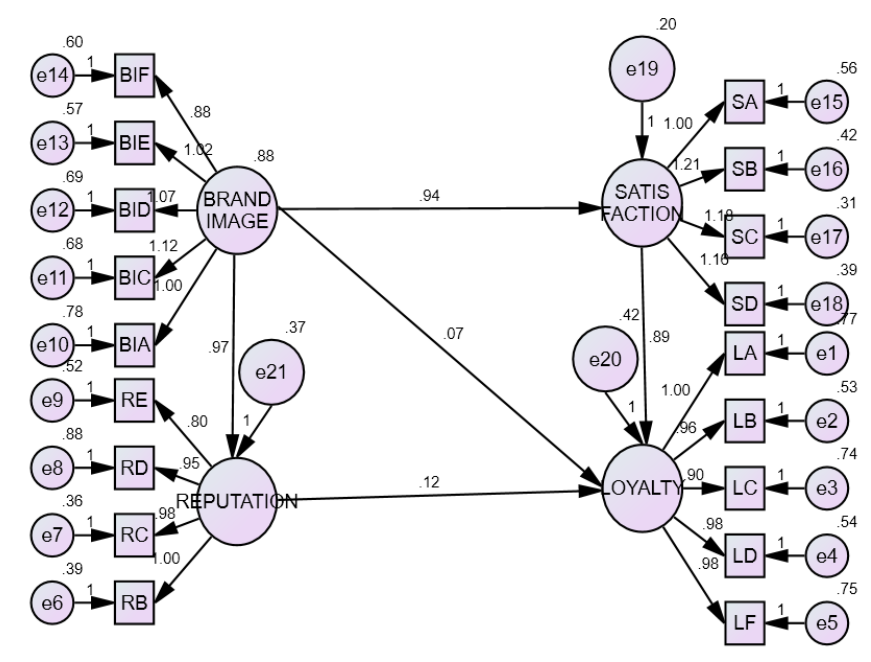

\section{DisCuSSIONS AND CONCLUSIONS}

This research has proven that satisfaction of customers is very important to create and maintain loyalty. Most of the respondents of this research are from the millennial age. The question now is how to fulfill their desires since brand image and reputation are not strong enough to influence their loyalty. So far, the environment or atmosphere and products provided by Hero Supermarket seems to influence the customers very much that the intention to come again in the future is very strong. On the other hand, the brand image of Hero is undeniably influencing satisfaction of customers. Customers feel that Hero suits their image shopping for products. They can depend on Hero to fulfill their needs and they feel Hero is doing their best to suit their interest. Hence, it is obvious that customers need to experience buying at the store, then feel satisfied before they can be loyal for the future.Thus, having a brand image does not guarantee to get loyal customers. But, instead, the brand image of a firm gives them a priority to be chosen as the first store to visit before visiting others. Once the customers feel satisfied, then they will become loyal and don't bother visiting other stores anymore. Brand image creates a reputation as well. Customers of Hero prefer to go to a reputable, prestigious, respected store rather than others. Image of Hero has turned into a reputed store among their customers. Unfortunately, the reputation doesn't guarantee the loyalty of customers. It seems customers just choose a reputed store, try the products and atmosphere, feel satisfied then only they want to be a loyal customer. This shows that a firm, in a retail store, needs to maintain their brand image and reputation to be chosen as the first choice of customers instead of thinking that brand image and reputation are the main drivers to lure customers' loyalty.

Hence, future researchers are advised to use service quality in the retail context (Dabholkar, Thorpe, \&Rentz, 1996; Kumar, 2014; Kumar, 2015; Kumar, Winarto, \& Astuti, 2015; Kumar, Ariyanti, Muharromah, \&Saragih, 2016; Kumar, 2016) to figure out the relationship with satisfaction and loyalty. Other than that, customer value is also considered as the driven factors for satisfaction and word-of-mouth (WOM) as the implication of loyalty(Rintamaki \& Kirves, 2017).

\section{REFERENCES}

[1] (2015). Asean Grocery Retail. Available at: https://www.dbs.com.sg/treasures/aics/pdfController.page? pdfpath=/content/article/pdf/AIO/150722_insights_whetting_asean_appetite.pdf.

[2] (2016). Top Brand Index 2016 Fase 2. Available at: http://www.topbrand-award.com/top-brandsurvey/survey-result/top_brand_index_2016_fase_2

[3] Aarikka-Stenroos, L. H. S. (2014). Industrial buyers' use of references, word-of-mouth and reputation in complex buying situation. Journal of business \& industrial marketing, 344-352.

[4] Abrudan, I.N., Plăiaş, I., Dabija, D.C.(2015). The Relationship among Image, Satisfaction and Loyalty Innovative Factor of Competitiveness for Shopping Centers, Amfiteatru Economic, 17 (39), 536-552.

[5] Apipudin. (2012). Brand Switching Analysis dalam Industri Ritel Modern. Available at: http://www.topbrand-award.com/article/brand-switching-analysis-dalam-industri-ritel-modern.html.

[6] Bhasin, H. (2016, December 3). Branding articles. Retrieved January 24, 2017, from Marketing91: http://www.marketing91.com/brand-image/ 
[7] Benoit, W.L. (2015), "Image restoration theory", in Donsbach, W. (Ed.), The Concise Encyclopedia of Communication, John Wiley \& Sons, Chichester, p. 251.

[8] Chegnini. (2010). Customer Loyalty: Toward an Integrate Conceptual Framework.

[9] Cretu, A. E., \&\& Brodie, R. J. (2007). The influence of brand image and company reputation where manufacturers market to small firms: A customer value perspective. Industrial Marketing Management 36, $230-240$.

[10] Dabholkar, P. A., Thorpe, D. I., \& Rentz, J. O. (1996). A Measure of Service Quality for Retail Stores: Scale Development and Validation. Journal of the Academy of Marketing Science, 24(1), 3-16. https://doi.org/10.1177/009207039602400101.

[11] Dagger, T. S., O'Brien, T. K. (2010) "Does experience matter?: Differences in relationship benefits, satisfaction, trust, commitment and loyalty for novice and experienced service users", European Journal of Marketing , 44 (9/10),1528-1552.

[12] Dick, A.S., Basu, K. (1994). Customer Loyalty: Toward an Integrate Conceptual Framework.Journal of the Academy of Marketing Science, 22(2), 99-113.

[13] Fianto, A. Y., Hadiwidjojo, D., \& Aisjah, \&. S. (2014). The Influence of Brand Image on Purchase Behaviour Through Brand Trust. Business Management and Strategy, 5 (2).

[14] Foroudi, P., Melewar, T., \& Gupta, S. (2014). linking corporate logo, corporate image and reputation: an examination of consumer perceptions in the financial setting. Journal of business research, 13.

[15] Foroudi, P., Jin, Z., Gupta, S., Melewar, T.C., Foroudi, M.M. (2016). Influence of innovation capability and customer experience on reputation and loyalty. Journal of Business Research, 69, 48824889.http://dx.doi.org/10.1016/j.jbusres.2016.04.047.

[16] Gallarza, M. G. (2016). Stretching the value-satisfactionloyalty. Management Decision, 54(4), 981 - 1003.

[17] García de Leaniz, P.M. \& del Bosque Rodriques, I.R. (2016). Corporate Image and Reputation as Drivers of Customer Loyalty. Corporate Reputation Review. 19(2),166-178. https: doi.org/10.1057/crr.2016.2.

[18] Joshi, J., Singh, A. (2017). Studying the impact of perceived corporate reputation on commitment and loyalty headed for customer citizenship behaviours in Telecon companies. Adhyayan: A Journal of Management Sciences, 7(02).https://doi.org/10.21567/adhyayan.v7i02.10764.

[19] Keller, K.L. (1993). Conceptualising, Measuring and Managing Customer-Based Brand Equity. Journal of Marketing, 57(1). 1-22.

[20] Kremer, F. and Viot, C. (2012), "How store brands build retailer brand image", International Journal of Retail \& Distribution Management, 40 (7), 528-543.

[21] Kumar, S. (2014). Customer Loyalty and The Impacts on Service Quality. Jurnal Hospitality dan Pariwisata. 1(1), 34-42.

[22] Kumar, S. (2015) The Influence of Retail Service Quality Towards Loyalty: A Survey at PT Santafi Travel's Customers in Cikarang (2015). Jurnal Hospitaliti Dan Pariwisata, 2(2). Available at SSRN: https://ssrn.com/abstract=2970347

[23] Kumar, S., Winarto, B., Astuti, M. (2015). The Impact of Service Quality, Facility, Price, Emotional Factor and Location on Customer Satisfaction and Loyalty at the 3-star Hotels in Bekasi. Buletin Studi Ekonomi. 20(1), 51-58.

[24] Kumar, S., Ariyanti, D., Muharromah, F.N. (2016). Customers' Perception of Perceived Website Service Quality and Its Implication on e-loyalty. Conducting Interdiciplinary Research, August 4-5, 2016. Bali.

[25] Kumar, S. (2016). Consumers' Perception towards Private Label and Its Implication on Repurchase Intention: A Case of Giant's Customers in Cikarang, Indonesia. Internatinal Journal of Managerial Studies and Research. 4(5), 1-6.

[26] Lahap, J., Ramli, N. S., Said, N. M., \& Radzi, S. M. (2016). A Study of Brand Image towards Customer's Satisfaction in the Malaysian Hotel Industry. Procedia Social and Behavioral Science, 149 - 157.

[27] Lauritsen, B. D., \& Perks, K. J. (2015). The influence of interactive, non-interactive, implicit and explicit CSR communication on young adults' perception of UK supermarkets' corporate brand image and reputation. Corporate communications: an international journal, 178-195.

[28] Loureiro, S.M.C., Sarmento, E.M., \& Le Bellago, G. (2017). The effect of corporate brand reputation on brand attachement and brand loyalty: Automobile sector. Cogent Business \& Management. 4: 136003. https://doi.org/10.1080/23311975.2017.1360031.

[29] Malhotra, N. K. (2007). Marketing research: An applied orientation. Upper Saddle River, NJ: Pearson/Prentice Hall.

[30] Manthiou, A., Kang, J., Schrier, T. (2014). A visitor-based brand equity perspective: the case of a public festival. Tourism Review , 69(4),264-283. https://doi.org/10.1108/TR-04-2014-0016. 
[31] Martenson, R. (2007). Corporate brand image, satisfaction and store loyalty. International Journal of Retail $\&$ Distribution Management, 35(7), 544-555.

[32] Nesset, E., Nervik, B. and Helgesen, O. (2011). Satisfaction and image as mediators ofstore loyalty drivers in grocery retailing. International Review of Retail, Distribution and Consumer Research, 21(3), 267-292.

[33] Neupane, R. (2015). The Effect of Brand Image on Customer satisfaction and Loyalty Intention in Retail Supermarket Chain UK. International Journal of Social Sciences and Management, 2(1), 9-26.DOI: http://dx.doi.org/10.3126/ijssm.v2i1.11814.

[34] Pasopati, G. (2015). Grup Ritel Hero Tutup 74 Gerai Akibat Perlambatan Ekonomi. Available at: https://www.cnnindonesia.com/ekonomi/20150918150532-92-79598/grup-ritel-hero-tutup-74-geraiakibat-perlambatan-ekonomi.

[35] Pleshko, L.P., Heiens, R.A. (2015). Customer satisfaction and loyalty in the Kuwaiti retail services market: why are satisfied buyers not always loyal buyers?, The International Review of Retail, Distribution and Consumer Research, 25:1, 55-71. DOI: 10.1080/09593969.2014.880936.

[36] Pulungan, A.M. (2017). Menegakkan DNI di Industri Ritel. BeritaSatu. Available at: http://www.beritasatu.com/opini/420458-menegakkan-dni-di-industri-ritel.html.

[37] Rintamäki, T., \& Kirves, K. (2017). From perceptions to propositions: Profiling customer value across retail contexts. Journal of Retailing and Consumer Services, 37(June), 159-167. https://doi.org/10.1016/j.jretconser.2016.07.016.

[38] Ruiz, B., García, J.A., Revilla, A.J. (2016) "Antecedents and consequences of bank reputation: a comparison of the United Kingdom and Spain", International Marketing Revie ,33(6),781-80. https://doi.org/10.1108/IMR-06-2015-0147.

[39] Seric, M., Gil-Saura, I., Molla-Descals, A. (2016), Can advanced technology affect customer-based brand equity in service firms? An empirical study in upscale hotels. Journal of Service Theory Practice, 27(5),958-979. https://doi.org/10.1108/IJCHM-12-2013-0568.

[40] Simorangkir, E. (2017). Ada 30 Ribu Toko Modern di RI, Bahayakah Bagi Pasar Tradisional? Detik. Available at: https://finance.detik.com/berita-ekonomi-bisnis/3670530/ada-30-ribu-toko-modern-di-ribahayakah-bagi-pasar-tradisional.

[41] Sondoh Jr., S. L., Omar, M. W., Wahid, N. A., Ishak, I., Harun, A. (2007). The effect of brand image on everall satisfaction and loyalty intention in the context of color cosmetic.Asian Academy of Management Journal, 12(1),83-107.

[42] Soon-Ho, K., Min-Seoung, K., \&Lee, D. H. (2016). The Effects of Personality Traits and Congruity on Customer Satisfaction and Brand Loyalty: Evidence from Coffee Shop Customers. Advances in Hospitality and Leisure.12(3), 3-33.http://dx.doi.org/10.1108/S1745-354220160000012001.

[43] Sumartomdjon, M. (2016). Hero lepas Starmart ke Family Mart. Available at: http://industri.kontan.co.id/news/hero-lepas-starmart-ke-family-mart.

[44] Vercic, A. T., Vercic, D., \& Znidar, K. (2016). Exploring academic reputation - is it a multidimensional construct? Corpotate communications: an international journal, 160-176.

\section{AUTHORS' BIOGRAPHY}

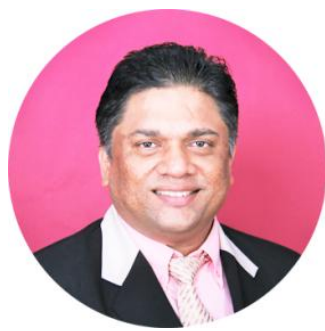

Suresh Kumar was born in Tanjungbalai, North Sumatra, Indonesia on September 7, 1976. Suresh Kumar was an executive director of Chamber of Commerce and Trade of Tanjungbalai Municipality from 2004 to 2008. He was an education consultant for Yayasan Vijaya (Vijaya Foundation) in 2004-2008. $\mathrm{He}$ is currently working as a lecturer at President University. He is a member of Association of Business Administration, Indonesia. Subjects taught are Retail Business, Operations Management, Research Method, and Management Information System.

Citation: Suresh Kumar. "Determinants of Customer Loyalty: Evidence from Indonesian Retail Market" International Journal of Managerial Studies and Research (IJMSR), vol 6, no. 3, 2018, pp. 17-24. doi:http://dx.doi.org/10.20431/2349-0349.0603003.

Copyright: () 2018 Authors. This is an open-access article distributed under the terms of the Creative Commons Attribution License, which permits unrestricted use, distribution, and reproduction in any medium, provided the original author and source are credited. 